\title{
Mandatory IFRS Adoption And Financial Analysts' Information Environment: Evidence From Korean Market
}

\author{
Saerona Kim, Soongeui Women's College, South Korea \\ Noolee Kim, Hanyang University-ERICA, South Korea \\ Kyoung-Min Kwon, Hongik University, South Korea
}

\begin{abstract}
The paper examines the effects of the mandatory adoption of International Financial Reporting Standards (IFRS) on financial analysts' information environment, specifically on analysts forecast accuracy in the Korean market. We find that financial analysts' forecast accuracy improves after the mandatory IFRS adoption. We further investigate the source of observed accuracy enhancements and find that the improved forecast accuracy is attributable to the increased precision in analysts' information sets for KOSPI firms and increased opportunity for earnings management for KOSDAQ firms. We also find that the analyst coverage in Korean market is reduced after mandatory IFRS adoption.
\end{abstract}

Keywords: IFRS; Mandatory Adoption; Analysts; Information Environment; Korean Market

\section{INTRODUCTION}

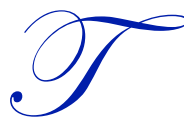

he adoption of International Financial Reporting Standards (IFRS) around the world represents the most important regulatory change for financial reporting in recent years. In 2005, the European Union member countries, Australia, and New Zealand required all publicly listed firms to switch to IFRS for financial reporting purposes. This move increased the pressure for Korean firms to switch from domestic accounting standards to IFRS with enhanced transparency and comparability of accounting numbers for international investors. In response to this increased pressure, Korean government required publicly listed firms and financial institutions in Korea to adopt IFRS by the end of 2011.

This study investigates how the recent mandatory adoption of IFRS affects financial analysts' information environment, specifically the accuracy of analysts' earnings forecasts in Korean market. Financial analysts are among the most important and sophisticated users of financial reporting service, and therefore examining the effects of IFRS adoption on analysts would enhance our understanding of the consequences of IFRS adoption. Especially, IFRS adoption in Korea provides a great opportunity to examine the issue because IFRS adoption produce more significant differences in financial reporting practices in Korea than many other countries where IFRS adoption has taken places. Before IFRS adoption, the primary financial statements of Korean firms required to be disclosed are standalone (unconsolidated) financial statements. However, IFRS adoption designate consolidated financial statements as the primary financial statements, which exert a strong influence on Kore an firms' financial reporting. Although many previous studies examined the issue, it is still controversial how mandatory IFRS adoption would affect financial analysts. On the one hand, proponents of IFRS claim that IFRS adoption has improved analysts' information environment, on the grounds that IFRS enhances the disclosure quality and transparency and/or increases the comparability of financial reporting (Bae, Tan, \& Welker, 2008; Barth, Landsman, \& Lang, 2008). On the other hand, opponents argue that IFRS adoption render financial reporting less informative, because "one size fits all" IFRS might be less reflective of domestic firms' unique financial position and operating performance (Ball, 2006) and thereby, IFRS adoption reduce the quality of analysts' information. 
In order to examine the effects of mandatory adoption of IFRS on financial analysts' information environment in Korea, we perform several empirical analyses. Firstly, we check whether the mandatory IFRS adoption is associated with the accuracy of analysts' earnings forecasts; absolute forecast errors and forecast dispersions. We find that mandatory IFRS adoption significantly reduce analysts' forecast errors and forecast dispersions, which suggests that mandatory IFRS adoption improves analysts' information environment. Secondly, we investigate if the increase of analysts' forecast accuracy is caused by increased opportunities for earnings management instead of the improvement in analysts' information sets. Managers have more opportunities under IFRS to manage their earnings towards analysts' forecasts because IFRS allows higher level of discretion in financial reporting. The results show that the accuracy in analysts' forecasts is enhanced partly by the increase earnings management after IFRS adoption. However, this effects are mainly concentrated in KOSDAQ firms. Thirdly, we examine whether the improvement in analysts' forecast accuracy is attributable to the increased precision in analysts' information sets. We find that mandatory IFRS adoption improves the precision of analysts' information sets. This, however, does not hold for KOSDAQ firms. Lastly, we study if mandatory IFRS adoption is associated with analysts' coverage. Unlike other countries employing consolidated financial statements as the primary financial statements even before IFRS adoption, the primary financial statements for Korean firms have been changed from unconsolidated ones to consolidated ones with IFRS adoption. As a result, financial analysts are required to spend more time and efforts to provide their earnings forecasts based on consolidated financial statements. The results show that the mandatory adoption of IFRS reduces analysts' coverage, suggesting that IFRS adoption in Korea has real effects on financial analyst in Korean market.

Our study contributes to the previous literature on financial reporting and disclosure by providing empirical evidence of the effects of mandatory IFRS adoption on analysts' information environment using Korean data. We exploit the unique situation for Korean firms surrounding IFRS adoption in our empirical design. Also, we investigate which attributes of IFRS generate the improvements in analysts' information environment. This study has important implications for policy makers and other users of financial statements who wish to evaluate and understand the effects of mandatory IFRS adoption, especially in emerging markets such as Korea.

The remainder of the paper is organized as follows. In Section 2, we review the previous literature and develop our hypotheses. Section 3 describes the sample selection procedure and the research design, and Section 4 presents the empirical results. Section 5 provides the robustness test results. In section 6, we summarize and conclude the paper.

\section{LITERATURE REVIEW AND HYPOTHESIS DEVELOPMENT}

\subsection{Background: IFRS Adoption}

Proponents of IFRS argue that publicly traded companies must apply a single set of high-quality accounting standards in order to promote better functioning of capital markets (Jarrett, 2007). According to them, mandatory IFRS adoption has the potential to facilitate cross-border comparability, increase reporting transparency, decrease information costs, reduce information asymmetry, and thereby increase the liquidity, competitiveness, and efficiency of markets (Ball, 2006; Choi \& Meek, 2005). As alleged by opponents of IFRS, however, if the "one size fits all" IFRS are not optimal than existing domestic accounting standards in reflecting firm performances, IFRS adoption would cause financial reporting to be less informative (Ball, 2006).

Prior studies have extensively examined the effects of IFRS adoption on financial analysts' information environment. It is still unclear, however, how IFRS adoption would affect analysts' information enviro nment. The adoption of IFRS in Korea presents propitious opportunity to study this unsolved question because Korea's unique regulatory and institutional features are significantly different from such countries as EU, Australia, and New Zealand which have adopted IFRS. Korean firms have experienced huge changes because their primary financial statements have been altered from unconsolidated ones to consolidated ones by IFRS adoption. Therefore, we can exploit this Korean case to investigate the difficulties and complexity which IFRS adoption might cause to users of financial statements, even to sophisticated users such as financial analysts. 


\subsection{IFRS and Analysts' Information Environment}

Early studies investigate the effects of voluntary adoption of IFRS on financial analysts' information environment. Specifically, Ashbaugh and Pincus (2001) and Bae et al. (2008) show that analysts benefit from improved consistency in firms' policy choices. Several studies find an overall improvements in the information environment of analysts (Hodgdon, Tondkar, Harless, \& Adhikari, 2008; Kim \& Shi, 2012).

Meanwhile, recent studies examine the effects of mandatory IFRS adoption on the information environment of analysts. However, the results are inconclusive. Even though overall findings support the improvements in analysts' information environment after IFRS adoption, there are several studies documenting the deterioration of information environment following IFRS adoption. Byard, Li, and Yu (2011) find decreases in forecast errors and dispersion after mandatory adoption, but only for firms in countries with strong enforcement regimes and domestic accounting standards which are significantly different from IFRS. Tan, Wang, and Welker (2011) find that forecast accuracy improves for foreign analysts after IFRS adoption but domestic analysts' forecast accuracy is not affected, and that the change in accuracy is not increasing in the number of accounting differences between domestic accounting standards and IFRS. They conclude that IFRS adoption overall produces comparability benefits that enhance the usability of accounting data. Cotter, Tarca, and Wee (2012) study the impacts of IFRS adoption on properties of analysts' forecast for Australian firms and find that analyst forecast accuracy improves but there is no change in dispersion in the adoption year. Glaum, Baetge, Grothe, and Oberdörster (2013) show that the quality of disclosure improves after IFRS adoption, but this finding explains only a small proportion of the overall improvements in forecast accuracy. As a result, it is unclear whether mandatory IFRS adoption improves the properties of analysts' forecasts.

\subsection{Hypothesis}

Our first hypothesis is about the impacts of IFRS adoption on the forecasts quality i.e. accuracy of financial analysts in Korea. The mandatory IFRS adoption in Korea might enhance the comparability and transparency of financial statements and therefore, improve analysts' forecast quality. This reasoning leads to our first hypothesis:

Hypothesis 1: The mandatory adoption of IFRS is positively associated with the accuracy of analysts' earnings forecasts.

Previous studies investigate whether IFRS adoption enhance analysts' information environment by examining absolute forecast errors, forecast dispersion, and the number of analysts following a firm. However, it is not clear whether they are truly caused by the improvements in analysts' information sets because there could be possible alternative causes. Ball, Kothari, and Robin (2000) argue that a firm's reporting incentive is the primary factor that determines the informativeness of accounting statements. Byard et al. (2011) highlight the important role of enforcement regimes and firm-level reporting incentives in determining the impacts of mandatory IFRS adoption. Therefore, the change after IFRS adoption might be generated by the change in firms' reporting incentives instead of the changes in analysts' information sets.

According to opponents of IFRS, IFRS has increased managerial flexibility and discretion especially due to the lack of implementation guidance and poor enforcement (Ahmed, Neel, \& Wang, 2013; Ball, Robin, \& Wu, 2003; Leuz, 2003). Also, earnings management might have a meaningful role in determining accounting quality surrounding mandatory IFRS adoption ${ }^{1}$. Ahmed et al. (2013) and Chen, Tang, Jiang, and Lin (2010) find evidence of an increase in income smoothing and a reduction in timeliness of loss recognition following mandatory IFRS adoption. Also, Ahmed et al. (2013) find a significant increase in aggressive reporting of some accruals and fail to find an evidence of the reduction in earnings management. These evidences suggest that there are increased opportunities for earnings management following mandatory IFRS adoption. Furthermore, several studies document that firms manage their

1 Paananen (2008) and Paananen and Lin (2009) find that mandatory IFRS adoption decreases financial reporting quality, increase s earnings management, and reduces timeliness of loss recognition in Germany. Jeanjean and Stolowy (2008) find no decline in the pervasi ven ess of earnings management in Austria and the United Kingdom and find increase in France.

Copyright by author(s); $\underline{\text { CC-B Y }}$

$\underline{\text { The Clute Institute }}$ 
earnings towards a certain target such as analysts' forecasts (Bannister \& Newman, 1996; Degeorge, Patel, \& Zeckhauser, 1999; Matsumoto, 2002; Abarbanell \& Lehavy, 2003; Hutton, 2005). Therefore, the documented increase in analysts' forecast accuracy could be a consequence of increased opportunities of earnings management to match their analysts' forecasts. If the improvement of forecasts accuracy after IFRS adoption is brought by the increased opportunities in earnings management, then the improved accuracy would be associated with increased level of earnings management. This consideration produces our second hypothesis:

Hypothesis 2: The increase in analysts' forecasts accuracy after mandatory IFRS adoption is associated with the increased level of earnings management.

In order to gain more detailed understanding of analysts' information environment, we also examine if the improved accuracy of analysts' earnings forecasts is attributable to the increased precision of analysts' information sets. Analysts generally utilize financial statements data as the main inputs to their models for earnings forecasts. Therefore, we are interested in examining whether and how mandatory IFRS adoption affects analysts' information sets for earnings forecasting. Byard and Shaw (2003) find that high-quality annual and quarterly reports increase the precision of both analysts' public information and private information ${ }^{2}$. Kim and Shi (2012) report that the added disclosures following voluntary IFRS adoption contribute to the enhanced precision of analysts' information set. Based on these findings, we conjecture that mandatory IFRS adoption sharpens the precision of analysts' information and therefore improves the quality of analysts' earnings forecasts. Therefore, we set our third hypothesis as follows:

Hypothesis 3: The increase in analysts' forecasts accuracy after mandatory IFRS adoption is associated with the increased precision of analysts' information sets.

Previous literature reports that the level of disclosure of a firm is positively related to the analyst coverage for the firm (Lang \& Lundholm, 1996; Healy, Hutton, \& Palepu, 1999). This relation is confirmed with international evidence (Hope 2003a; Lang, Lins, \& Miller, 2003). However, the empirical evidence for analyst coverage in IFRS literature are somewhat mixed. Byard et al. (2011) find that mandatory adopters exhibit no statistically significant change in analyst following in the European Union. Unlike Byard et al. (2011), Tan et al. (2011) find that mandatory IFRS adoption attracts more foreign analysts. These findings suggest that benefits from IFRS adoption might not be uniform across countries.

Unlike other countries which have adopted IFRS, Korea experienced significant changes in accounting practices especially in primary financial statements. In post-IFRS period, we can expect that financial analysts are required to spend more time and efforts in providing accurate forecasts, because they have to use consolidated financial statements. Therefore, we conjecture that mandatory IFRS adoption reduces the number of analys ts following. This expectation leads to our fourth hypothesis:

Hypothesis 4: IFRS mandatory adoption is as sociated with decreased coverage by analysts.

\section{SAMPLE SELECTION AND RESEARCH DESIGN}

\subsection{Sample Selection}

We tests our hypotheses using a sample of Korean listed firms over the period from 2000 to 2013 . We obtain annual financial data from Kis Value III and one-year ahead earnings per share forecasts from Fn-guide ${ }^{3}$. Following Clement (1999), we make sure that no earnings forecasts are issued earlier than one year before the given fiscal

2 Byard et al. (2011) investigate the effects of mandatory IFRS adoption on analysts' information quality based on Barron, Kim, Lim, and Stevens (1998)'s model. They document improvements relative to the control sample in analysts' public and private information precision for mandatory adopters in countries with strong enforcement regimes and large divergence from IFRS.

3 KisValue III and Fn-guide are Korean databases that provide financial data and analyst coverage. They are similar to COMPUST AT and I/B/E/S dat abase, respectively.

Copyright by author(s); $\underline{\mathrm{CC}-\mathrm{B} Y}$

The Clute Institute 
year-end. We also exclude forecasts that are released after actual earnings announcement dates or 3 months after the given fiscal year-end.

We restrict our sample to non-financial and non-utility firms because financial and utility firms operate in highly regulated industries with different accounting rules from those in other industries. We exclude firms that adopted IFRS before 2011 because they reported financial statements for the 2010 fiscal year in accordance with IFRS. Further, each firm-year observation is required to have a fiscal year ending in December in order to ensure homogeneity across sample firms. We exclude firms without financial or stock return data available. This procedure results in our final sample of 3,715 firm-year observations. We control for the influence of observations with extreme value by winsorizing dependent and independent variables at the $1 \%$ and $99 \%$ levels.

\subsection{Measuring Analysts' Information Environment}

We measure the characteristics of analysts' information environment using Absolute forecast errors, Forecast dispersion, and Analyst coverage (FLLW) (Byard et al., 2011; Kim \& Shi, 2012).

$$
\text { Absolute forecast errors }(A F E)=\frac{\mid \text { Actual Earnings }- \text { Mean forecast } \mid}{\text { Stock price }}
$$

where

Actual Earnings: actual annual EPS of firm $i$ in year $t$

Mean forecast: the mean of EPS forecasts made by analysts during the 12-month period before the fiscal year-end for firm $i$ and year $t$,

Stock price: the stock price of firm $i$ at the beginning of year $t^{4}$.

$$
\begin{aligned}
& \text { Forecast dispersion }(D I S P)=\frac{\text { Standard deviation of forecasts }}{\text { Stock price }} \\
& F L L W=\ln (\text { the number of analysts forecasting EPS of a firm) }
\end{aligned}
$$

\subsection{Measuring Information Precision}

We follow Barron et al. (1998) to empirically measure the precision of information that analyst incorporate into their earnings forecasts. Our main test uses the precision of total (public and private) information, $K$, as the dependent variable. We also examine the impacts of mandatory IFRS adoption on the precision of public information that is common to all analysts (PUBLIC), the precision of private information that is idiosyncratic to an individual analyst (PRIVATE), and analysts' consensus which is the average proportion of analysts' public to total information (CONSENSUS).

$$
\begin{aligned}
& \text { PUBLIC }(\text { Common })=\frac{S E-D / N}{[(1-1 / N) D+S E]^{2}} \\
& \text { PRIVATE (Idiosyncratic) }=\frac{D}{[(1-1 / N) D+S E]^{2}} \\
& \text { CONSENSUS }=\frac{\text { PUBLIC }}{(\text { PUBLIC+PRIVATE) }} \\
& K(\text { Total information })=\text { PUBLIC }+ \text { PRIVATE }
\end{aligned}
$$

4 The results in the analysis using the median forecast are qualit atively similar. 
where

$S E=$ the expected squared error in the mean forecast

$D=$ the expected forecast dispersion

$N=$ the number of forecasts for firm $i$ in year $t$

We limit our data to the most recent one-year-ahead forecasts of annual earnings. We use the within-year fractional rank of $K$ (denoted as $R K$ ) to reduce the influence of outliers and skewness. Specifically, we transform $P U B L I C$, PRIVATE and CONSENSUS into [0, 1] decile ranks ${ }^{5}$.

\subsection{Research Design}

To test Hypothesis 1 and investigate differences in the properties of analysts' forecasts surrounding IFRS mandatory compliance we construct a regression equation. Our approach follows prior studies that employ the characteristics of analysts' forecasts as proxies for the information environment (Lang \& Lundholm, 1996; Healy et al., 1999; Lang et al., 2003). We use two measures to capture analysts' information environment for a firm: absolute forecast errors, forecast dispersion. This yields the following regression equation:

$$
\begin{aligned}
& A F E_{i t}(\text { or DISP } \\
& \left.\quad+\beta_{6}\right)=\beta_{0}+\beta_{1} \text { IFRS }_{i t}+\beta_{7}+\beta_{2} A B A C \text { HOR }_{i t}+\beta_{3} S I Z E_{i t}+\beta_{8} F L L W_{i t}+\Sigma I N D+\beta_{4} L E V_{i t}+\beta_{5} L O S S_{i t} \\
& \quad
\end{aligned}
$$

$A F E$ and DISP are the absolute forecast errors and the forecast dispersion for firm $i$ and year $t$, respectively. IFRS is an indicator variable that takes the value of one if firm $i$ adopted IFRS in year $t$. We only include mandatory adopters in our sample because firms that have already voluntarily switched to IFRS prior to the mandate may not exhibit significant effects when IFRS reporting becomes mandatory (Daske, Hail, Leuz, \& Verdi, 2008). The key coefficient of interest, $\beta_{1}$, captures the difference in analysts' information environment between the test and control firms, and therefore, the impacts of mandatory IFRS adoption on analysts' forecasts accuracy. If IFRS adoption improves the accuracy of analysts' forecasts, then $\beta_{1}$ would have significantly negative value.

Previous research (Clement, 1999; Duru \& Reeb, 2002) suggests various factors that might affect forecast errors and dispersion. Control variables include the level of absolute accruals ( $A B A C C)$, the natural logarithm of total asset $(S I Z E)$, debt ratio $(L E V)$, reporting negative income $(L O S S)$, current year's return on as sets $(R O A)$, forecast horizon $(H O R I Z O N)$, and analyst coverage $(F L L W)$. Specifically, $A B A C C$ is calculated as absolute value of income before extraordinary items minus cash flow from operations deflated by total assets. $L E V$ is the ratio of short and long term debt to total assets. LOSS is a dummy variable set to one if the firm has negative earnings for the fiscal year and zero otherwise. ROA is the ratio of earnings before interest and taxes to total as sets. HORIZON is the natural logarithm of the number of days between the forecast is suing date and the fiscal year-end. We measure analyst coverage (FLLW) as the natural logarithm of the number of analysts making EPS forecasts of a firm. We also include industry fixed effects (IND) and use adjusted standard errors for firm-level clustering to mitigate serial correlation within a firm (Ahmed et al., 2013).

Second equation is to test Hypothesis 2 and examine whether earnings management can explain the changes in forecast accuracy. Specifically, we investigate whether forecast accuracy improves more for IFRS adopter firms that have large absolute discretionary accruals. Prior studies find that firms followed by analysts who issue earnings forecasts exhibit lower earnings management (DeFond \& Hung, 2003; McInnis \& Collins, 2011). Control variables used in (8) are also included:

$$
\begin{aligned}
& A F E_{i t}=\beta_{0}+\beta_{1} I_{F R S_{i t}}+\beta_{2} A B S D A_{i t}+\beta_{3} I_{F R S_{i t}} \times A B S D A_{i t}+\beta_{4} S I Z E_{i t}+\beta_{5} L E V_{i t} \\
& \quad+\beta_{6} L_{\text {OSS }}+\beta_{7 t} \text { ROA }_{i t}+\beta_{8} \text { HORIZON }_{i t}+\beta_{9} F L L W_{i t}+\Sigma I N D+\varepsilon_{i t}
\end{aligned}
$$

5 We rank each raw variable into 0-9 and then divide the decile ranks by 9 (Botosan, Plumlee, \& Xie, 2004; Byard et al., 2011). 
We estimate absolute discretionary accruals $(A B S D A)$ using the modified Jones model (Dechow, Sloan, \& Sweeney, 1995). If the increase of forecast accuracy is caused by earnings management, then $\beta_{3}$ would be significantly negative.

We test Hypothesis 3 and study the relation between the precision of analysts' information sets $(R K)$ and IFRS adoption to check whether mandatory IFRS adoption increases the precision of the analysts' information sets. Specifically, we estimate the following regression equation:

$$
\begin{aligned}
& R K_{i t}=\beta_{0}+\beta_{1} I_{F R} S_{i t}+\beta_{2} A B A C C_{i t}+\beta_{3} S I Z E_{i t}+\beta_{4} L E V_{i t}+\beta_{5} L O S S_{i t}+\beta_{6} R O A_{i t} \\
& +\beta_{7} H O R I Z O N_{i t}+\beta_{8} F L L W_{i t}+\Sigma I N D+\varepsilon_{i t}
\end{aligned}
$$

In Equation (10), we include several control variables used in previous studies (Byard \& Shaw, 2003; Chung, Kim, \& Kim, 2004; Kim \& Yi, 2011). All variables are as defined above.

In order to test Hypothesis 4, we estimate a regression equation which links IFRS adoption to analyst coverage. We incorporate various determinants of analyst coverage identified in previous literature in our multivariate regression equation as control variables (Bhushan, 1989; Hope, 2003a, 2003b; Lang \& Lundholm, 1996; Lang et al., 2003). This yields the following regression equation:

$$
\begin{aligned}
& F_{L L W_{i t}}=\beta_{0}+\beta_{1} I_{F R S_{i t}}+\beta_{2} A B A C C_{i t}+\beta_{3} S I Z E_{i t}+\beta_{4} L E V_{i t}+\beta_{5} L O S S_{i t} \\
& +\beta_{6} \text { ROA }_{i t}+\beta_{7} \text { HORIZON }_{i t}+\beta_{8} \text { DISP }_{i t}+\Sigma I N D+\varepsilon_{i t}
\end{aligned}
$$

All variables are as defined above. If IFRS adoption is associated with decreased coverage by analysts, then our fourth hypothesis predicts a significantly negative value for $\beta_{1}$.

\section{EMPIRICAL RESULTS}

Table 1 reports descriptive statistics for various subsamples and univariate tests for the difference in mean and median between the IFRS adoption sample (IFRS=1) and non-adoption sample (IFRS=0). The mean (median)

\begin{tabular}{|c|c|c|c|c|c|c|}
\hline \multicolumn{7}{|c|}{ Panel A: Full Sample (A) and $I F R S=1(\mathrm{~B})$} \\
\hline & \multicolumn{3}{|c|}{ Full Sample (A) } & \multicolumn{3}{|c|}{$I F R S=1(\mathrm{~B})$} \\
\hline & Mean & Median & Std. Dev. & Mean & Median & Std. Dev. \\
\hline \multicolumn{7}{|c|}{ Dependent Variables } \\
\hline$\overline{A F E}$ & 0.073 & 0.018 & 0.526 & 0.041 & 0.018 & 0.113 \\
\hline DISP & 0.006 & 0.000 & 0.020 & 0.004 & 0.000 & 0.014 \\
\hline$F L L W$ & 0.899 & 0.693 & 1.013 & 0.585 & 0.000 & 0.907 \\
\hline$R K$ & 0.498 & 0.444 & 0.319 & 0.511 & 0.556 & 0.318 \\
\hline \multicolumn{7}{|c|}{ Control Variables } \\
\hline$\overline{A B S D A}$ & 0.084 & 0.055 & 0.091 & 0.066 & 0.043 & 0.071 \\
\hline$A B A C C$ & 0.093 & 0.060 & 0.102 & 0.071 & 0.047 & 0.079 \\
\hline SIZE & 25.159 & 25.051 & 1.704 & 25.757 & 25.506 & 1.399 \\
\hline$L E V$ & 0.440 & 0.435 & 0.337 & 0.407 & 0.405 & 0.203 \\
\hline LOSS & 0.209 & 0.000 & 0.407 & 0.242 & 0.000 & 0.428 \\
\hline$R O A$ & 0.054 & 0.053 & 0.127 & 0.041 & 0.038 & 0.083 \\
\hline HORIZON & 5.041 & 5.167 & 0.582 & 4.967 & 5.128 & 0.616 \\
\hline
\end{tabular}
absolute forecast errors $(A F E)$, forecast dispersion $(D I S P)$ are $0.073(0.018)$ and $0.006(0.000)$ respectively for the full sample.

Table 1. Descriptive Statistics and Tests of Difference

(T able 1, Panel B continued on next page) 
(Table 1 continued)

Panel B: $\operatorname{IFRS}=0(\mathrm{C})$ and Test for Difference (B-C)

\begin{tabular}{|c|c|c|c|c|c|}
\hline & \multicolumn{3}{|c|}{$I F R S=0(\mathrm{C})$} & \multicolumn{2}{|c|}{ Test for Difference (B-C) } \\
\hline & Mean & Median & Std. Dev. & $\begin{array}{c}\text { Mean } \\
\text { (t-value) }\end{array}$ & $\begin{array}{c}\text { Median } \\
\text { (z-value) }\end{array}$ \\
\hline \multicolumn{6}{|c|}{ Dependent Variables } \\
\hline$A F E$ & 0.093 & 0.017 & 0.667 & $-3.03^{n+1}$ & 0.59 \\
\hline$D I S P$ & 0.008 & 0.001 & 0.023 & $-6.17^{* * *}$ & $-9.38^{* * *}$ \\
\hline$F L L W$ & 1.005 & 0.693 & 1.015 & -15.06 & $-15.19^{\cdots \cdots n}$ \\
\hline$R K$ & 0.500 & 0.556 & 0.319 & 0.95 & -0.82 \\
\hline \multicolumn{6}{|c|}{ Control Variables } \\
\hline$A B S D A$ & 0.090 & 0.060 & 0.096 & $-15.66^{\prime \prime \prime}$ & -14.23 \\
\hline$A B A C C$ & 0.099 & 0.064 & 0.107 & $-16.42^{\cdots \cdots \cdots}$ & $-14.97^{\ldots \cdots \cdots}$ \\
\hline SIZE & 24.969 & 24.876 & 1.729 & $28.86^{* * *}$ & $28.95^{* * *}$ \\
\hline$L E V$ & 0.450 & 0.442 & 0.367 & $-7.75^{\text {*** }}$ & $-7.74^{\text {*** }}$ \\
\hline LOSS & 0.200 & 0.000 & 0.400 & $6.31^{* * * *}$ & 0.88 \\
\hline$R O A$ & 0.058 & 0.058 & 0.137 & $-7.94^{* * *}$ & $-16.84^{* * *}$ \\
\hline HORIZON & 5.061 & 5.176 & 0.571 & $-5.99^{* * * *}$ & $-5.34^{\text {*** }}$ \\
\hline
\end{tabular}

$A F E$ is absolute forecast errors and calculated as $\mid$ Actual Earnings-Mean forecast $\mid$ /Stock price, where Actual Earnings is act ual annual EP S for firm $i$ in year $t$, Mean forecast is the mean of forecasts made by analy sts during the 12-month period before the fiscal year-end for firm $i$ and year $t$, and Stock price is the stock price of firm $i$ at the beginning of year $t$. DISP is forecast dispersion for firm $i$ in year $t$ and calculated as Stand ard deviation of forecasts/Stock price.FLLWis analyst coverage and calculated as the natural logarithm of the number of analysts $m$ aking an EPS forecast of a firm. $K$ is measured as the sum of the precision of public information (PUBLIC) and private information (PRIVATE) and then we use the within-year fractional rank of $K$ to calculate $R K$. IFRS is an indicator variable that takes the value of one if firm $i$ 's financial statements are prepared under IFRS in year $t$, zero otherwise. ABSDA is measured using the modified Jones model (Dechow et al., 1995). ABACC is calculat ed as absolute value of income before extraordinary items minus cash flow from operations deflated by total assets. SIZE is the natural logarithm of total assets. $L E V$ is the ratio of short and long term debt to total assets. LOSS is a dummy variable set to one if the firm has negative earnings for the fiscal year, zero otherwise. ROA is the ratio of earnings before interest and taxes to total assets. HORIZON is the natural logarith $\mathrm{m}$ of $\mathrm{the}$ number of days between the forecast issuing date and the fiscal year-end. The symbols $* * *, * *$, and $*$ denote significance at the $1 \%, 5 \%$, and $10 \%$ levels, respectively.

Non-adoption sample is larger than IFRS adoption sample in the level of absolute forecast errors $(A F E)$ and forecast dispersion $(D I S P)$. This suggests that mandatory IFRS adoption leads to decreased absolute forecast errors and forecast dispersion. The mean (median) natural logarithm of the number of analyst ( $F L L W)$, is 0.899 (0.693) for the full sample, while it is 0.585 and $1.005(0.000$ and 0.693$)$ for the IFRS adoption (IFRS=1) and non-adoption sample $(I F R S=0)$, respectively. Both $\mathrm{t}$ - and z-tests show that $F L L W$ is significantly lower for IFRS adoption period than for non-adoption period, implying that mandatory IFRS adoption affects financial analysts' behaviors and makes them to cover less firms with IFRS adoption. On the other hand, the precision of analyst information sets $(R K)$ exhibits no significant difference between the two subsamples, which indicates that the information precision in IFRS adoption period is not meaningfully different from that in non-adoption period. The level of absolute discretionary accruals $(A B S D A)$ and absolute accruals $(A B A C C)$ are different across the two subsamples. We find that absolute discretionary accruals and absolute accruals are reduced significantly from years before IFRS adoption to years after IFRS adoption. The univariate analyses provides primitive evidence for our research questions, partially s uggesting that mandatory IFRS adoption might improve analysts'information environment.

We also find that size (SIZE) and frequency of net loss (LOSS) increase, but debt ratio (LEV), profitability (ROA), and the forecast horizon (HORIZON) decrease substantially after IFRS adoption.

Table 2 presents Pearson correlations among main variables. IFRS is negatively correlated with AFE, DISP, and $F L L W$, indicating that mandatory IFRS adoption might reduce earnings forecast errors, forecast dispersion and analyst coverage. Both $A B S D A$ and $A B A C C$ are negatively correlated with IFRS, suggesting that IFRS adoption results in reduced accruals. However, IFRS is not significantly correlated with $R K$, suggesting no evidence that mandatory IFRS adoption results in more precise information available to analysts. Also, IFRS is positively correlated with SIZE and LOSS and negatively correlated with LEV, ROA and HORIZON. 
Table 2. Pearson Correlation Matrix

\begin{tabular}{|c|c|c|c|c|c|c|c|c|c|c|c|}
\hline & 1 & 2 & 3 & 4 & 5 & 6 & 7 & 8 & 9 & 10 & 11 \\
\hline 1. $A F E$ & 1 & & & & & & & & & & \\
\hline 2. DISP & $0.07^{* * * *}$ & 1 & & & & & & & & & \\
\hline 3. FLLW & $-0.05^{* * *}$ & $0.22^{* * *}$ & 1 & & & & & & & & \\
\hline 4. $R K$ & $-0.11^{* * *}$ & $-0.14^{* * *}$ & $-0.34^{* * *}$ & 1 & & & & & & & \\
\hline 5. IFRS & $-0.05^{* * *}$ & $-0.10^{* * *}$ & $-0.18^{* * *}$ & 0.020 & 1 & & & & & & \\
\hline 6. $A B S D A$ & $0.13^{* * *}$ & $0.09^{* * * *}$ & $-0.05^{* * *}$ & 0.010 & $-0.11^{* * *}$ & 1 & & & & & \\
\hline 7. $A B A C C$ & $0.14^{* * * *}$ & $0.09^{* * *}$ & 0.000 & -0.020 & $-0.11^{* * *}$ & $0.87^{* * *}$ & 1 & & & & \\
\hline 8. SIZE & 0.000 & $0.15^{* * *}$ & $0.60^{* * *}$ & $-0.53^{* * *}$ & $0.19^{* * * *}$ & $-0.21^{* * *}$ & $-0.22^{* * * *}$ & 1 & & & \\
\hline 9. $L E V$ & $0.13^{* * *}$ & $0.14^{* * *}$ & $0.12^{* * *}$ & $-0.18^{* * *}$ & $-0.05^{* * *}$ & $0.13^{* * *}$ & $0.16^{* * * *}$ & $-0.02^{* * *}$ & 1 & & \\
\hline 10. LOSS & $0.12^{* * * *}$ & $0.07^{* * *}$ & $-0.06^{* * *}$ & $-0.17^{* * *}$ & $0.04^{* * * *}$ & $0.13^{* * *}$ & $0.18^{* * *}$ & $-0.06^{* * *}$ & $0.15^{* * *}$ & 1 & \\
\hline 11. $R O A$ & $-0.07^{* * *}$ & $-0.04^{* * *}$ & $0.12^{* * *}$ & $0.12^{* * *}$ & $-0.05^{* * *}$ & $-0.07^{* * *}$ & $-0.08^{* * *}$ & $0.03^{* * *}$ & $-0.19^{* * *}$ & $-0.49^{* * *}$ & 1 \\
\hline 12. HORIZON & 0.010 & 0.020 & $0.17^{* * *}$ & $-0.28^{* * *}$ & $-0.07^{* * *}$ & $-0.07^{* * *}$ & $-0.07^{* * *}$ & $0.12^{* * * *}$ & $0.05^{* * *}$ & $0.07^{* * * *}$ & $-0.11^{\text {*** }}$ \\
\hline
\end{tabular}

All variables are as defined in Table 1 . The symbols ***,**, and $*$ denote significance at the $1 \%, 5 \%$, and $10 \%$ levels, respectively.

Table 3 shows the estimated results of regression equation (8). We also present the estimated coefficients for different subsamples. Columns (1) and (2) show the result for the whole sample period. Columns (3) and (4) show the estimates when year 2009 and 2010 are excluded. During these two years, some Korean firms had voluntarily adopted IFRS. Columns (5) and (6) show the estimation result over the period from 2007 to 2013. This period is regarded to be homogeneous in terms of economic conditions and therefore more comparable ${ }^{6}$.

As shown in Table 3, the mandatory IFRS adoption in Korea reduces the absolute forecast error and forecast dispersion substantially. The negative coefficients on IFRS are statistically significant at 1 percent level in models (1), (2), (3), and (5) and at 5 percent level in model (4). These results imply that forecast accuracy improves significantly after mandatory IFRS adoption. This finding is valid in full sample period as well as in various subperiods $^{7}$, and supports our first hypothesis.

$6 \mathrm{We}$ also try alternative periods such as from 2008 or 2009 to 2013 and find qualit atively similar results. 7 In unreported tests, we find that the results are qualitatively similar for KOSPI and KOSDAQ subsamples. 
Table 3. OLS regression of analy sts' forecast accuracy on mandatory IFRS Adoption

\begin{tabular}{|c|c|c|c|c|}
\hline \multicolumn{5}{|c|}{ Panel A: 2000-2013 and Excluding 2009-2010 } \\
\hline Sample Period: & \multicolumn{2}{|c|}{$2000-2013$} & \multicolumn{2}{|c|}{ Excluding 2009-2010 } \\
\hline Dependent Variables: & AFE(1) & DISP(2) & AFE(3) & DISP(4) \\
\hline \multirow{2}{*}{ IFRS (indicator) } & $-0.041^{* * 2}$ & $-0.002^{* * * *}$ & $-0.031^{\text {** }}$ & $-0.001^{* *}$ \\
\hline & $(-3.339)$ & $(-3.547)$ & $(-3.005)$ & $(-1.973)$ \\
\hline \multirow{2}{*}{$A B A C C$} & 0.755 & 0.025 & $0.340^{3+\cdots}$ & $0.018^{*}$ \\
\hline & $(1.511)$ & $(1.489)$ & $(2.258)$ & $(1.670)$ \\
\hline \multirow{2}{*}{$S I Z E$} & 0.001 & -0.000 & -0.016 & 0.000 \\
\hline & $(0.056)$ & $(-0.712)$ & $(-1.034)$ & $(0.084)$ \\
\hline \multirow{2}{*}{$L E V$} & $0.256^{* *}$ & $0.008^{* * 3 *}$ & $0.200^{*}$ & $0.006^{* * *}$ \\
\hline & $(2.422)$ & $(3.803)$ & $(1.746)$ & $(2.433)$ \\
\hline \multirow{2}{*}{ LOSS } & $0.145^{2 \cdots, n}$ & 0.003 & $0.091^{m+n}$ & 0.002 \\
\hline & $(2.851)$ & $(1.578)$ & $(2.270)$ & $(1.280)$ \\
\hline \multirow{2}{*}{$R O A$} & 0.169 & -0.008 & -0.016 & -0.006 \\
\hline & $(1.145)$ & $(-1.579)$ & $(-0.196)$ & $(-1.260)$ \\
\hline \multirow{2}{*}{ HORIZON } & 0.021 & -0.001 & 0.009 & $0.001^{\prime \prime}$ \\
\hline & $(1.223)$ & $(-1.114)$ & $(0.508)$ & $(1.668)$ \\
\hline \multirow{2}{*}{$F L L W$} & -0.038 & 0.004 & -0.019 & 0.003 \\
\hline & $(-2.023)$ & $(7.448)$ & $(-2.039)$ & $(5.529)$ \\
\hline \multirow{2}{*}{ Intercept } & -0.183 & 0.017 & 0.405 & -0.001 \\
\hline & $(-0.396)$ & $(1.308)$ & $(1.411)$ & $(-0.070)$ \\
\hline Industry dummies & Yes & Yes & Yes & Yes \\
\hline No. of observations & 3,715 & 3,601 & 2,715 & 2,601 \\
\hline Adjusted R-square & 0.047 & 0.076 & 0.047 & 0.076 \\
\hline
\end{tabular}

Panel B: 2007-2013

\begin{tabular}{|c|c|c|}
\hline Sample Period: & \multicolumn{2}{|c|}{$2007-2013$} \\
\hline Dependent Variables: & AFE(5) & $\operatorname{DISP}(6)$ \\
\hline \multirow{2}{*}{ IFRS (indicator) } & $-0.033^{\text {***\% }}$ & $-0.002^{* * * *}$ \\
\hline & $(-2.736)$ & $(-4.009)$ \\
\hline \multirow{2}{*}{$A B A C C$} & 0.727 & 0.030 \\
\hline & $(1.253)$ & $(1.583)$ \\
\hline \multirow{2}{*}{ SIZE } & 0.012 & -0.000 \\
\hline & $(0.889)$ & $(-0.605)$ \\
\hline \multirow{2}{*}{$L E V$} & $0.135^{* *}$ & $0.010^{* * * *}$ \\
\hline & $(2.006)$ & $(3.981)$ \\
\hline \multirow{2}{*}{ LOSS } & 0.088 & 0.003 \\
\hline & $(1.473)$ & $(1.377)$ \\
\hline \multirow{2}{*}{$R O A$} & 0.068 & -0.006 \\
\hline & $(0.502)$ & $(-1.153)$ \\
\hline \multirow{2}{*}{ HORIZON } & 0.007 & -0.001 \\
\hline & $(0.542)$ & $(-1.347)$ \\
\hline \multirow{2}{*}{$F L L W$} & -0.031 & $0.004^{3+4}$ \\
\hline & $(-1.523)$ & $(7.362)$ \\
\hline \multirow{2}{*}{ Intercept } & -0.375 & 0.017 \\
\hline & $(-0.806)$ & $(1.247)$ \\
\hline Industry dummies & Yes & Yes \\
\hline No. of observations & 3,139 & 3,141 \\
\hline Adjusted R-square & 0.052 & 0.084 \\
\hline
\end{tabular}


Table 4 provides the estimation results for equation (9). Here, we test whether the improvements in analysts' forecast accuracy after IFRS adoption are attributable to increased opportunities for earnings management. In full sample, the estimated coefficient on the interaction term IFRS $\times A B S D A$ is negative but not statistically significant. Only in the sub-period without year 2009 and 2010 the coefficient is negative and significant at the 10 percent level (model (2)). In the subsample of KOSPI firms, the coefficient on the interaction term is negative but not significant.

However, the coefficient on the interaction term IFRS $\times A B S D A$ is negative and significant in the subsample of KOSDAQ firms. This is consistent with the earnings management explanation as it indicates that the reduction in the forecast errors after IFRS adoption is more pronounced for firms which have large discretionary accruals, in other words, more opportunities to manage earnings. This empirical evidence suggests that the improved analyst forecast accuracy after IFRS adoption is mainly driven by earnings manipulation in KOSDAQ firms but not in KOSPI firms. This result is partially consistent with Hypothesis 2.

Table 4. OLS regression of analy sts' forecast accuracy on earnings management

\begin{tabular}{|c|c|c|c|c|c|c|}
\hline \multicolumn{7}{|c|}{ Panel A: Full sample firms and KOSPI firms } \\
\hline & \multicolumn{3}{|c|}{ Full sample firms } & \multicolumn{3}{|c|}{ KOSPIfirms } \\
\hline Dependent Variables: & & $\overline{A F E}$ & & & $\overline{A F E}$ & \\
\hline \multirow[t]{2}{*}{ Sample Period: } & 2000-2013 & $\begin{array}{l}\text { Excluding } \\
2009-2010\end{array}$ & 2007-2013 & 2000-2013 & $\begin{array}{l}\text { Excluding } \\
2009-2010\end{array}$ & 2007-2013 \\
\hline & (1) & (2) & (3) & (4) & (5) & $(6)$ \\
\hline \multirow{2}{*}{ IFRS (indicator) } & 0.029 & -0.005 & 0.038 & 0.094 & 0.020 & 0.085 \\
\hline & $(0.610)$ & $(-0.241)$ & $(0.657)$ & $(0.927)$ & $(0.403)$ & $(0.622)$ \\
\hline \multirow{2}{*}{$A B S D A$} & 1.111 & $0.398^{* *}$ & 1.188 & 2.788 & $1.035^{*}$ & 2.962 \\
\hline & $(1.389)$ & $(1.989)$ & $(1.223)$ & $(1.401)$ & $(1.717)$ & $(1.161)$ \\
\hline \multirow{2}{*}{$I F R S \times A B S D A$} & -1.184 & -0.460 & -1.145 & -2.955 & -1.077 & -2.189 \\
\hline & $(-1.384)$ & $(-1.665)$ & $(-1.094)$ & $(-1.346)$ & $(-1.450)$ & $(-0.707)$ \\
\hline \multirow{2}{*}{$S I Z E$} & 0.001 & -0.017 & 0.013 & -0.002 & -0.044 & 0.019 \\
\hline & $(0.086)$ & $(-1.068)$ & $(0.915)$ & $(-0.062)$ & $(-1.226)$ & $(0.833)$ \\
\hline \multirow{2}{*}{$L E V$} & $0.274^{*}$ & $0.225^{\circ}$ & $0.141^{\circ}$ & $0.445^{n}$ & 0.322 & 0.222 \\
\hline & $(2.371)$ & $(1.766)$ & $(1.956)$ & (2.101) & $(1.506)$ & $(1.531)$ \\
\hline \multirow{2}{*}{$L O S S$} & $0.155^{* * *}$ & $0.094^{\text {** }}$ & 0.096 & $0.295^{* * * *}$ & $0.180^{* *}$ & 0.004 \\
\hline & $(2.732)$ & $(2.185)$ & $(1.420)$ & $(2.618)$ & (2.137) & $(0.020)$ \\
\hline \multirow{2}{*}{$R O A$} & 0.216 & 0.019 & 0.108 & 0.289 & -0.268 & 0.766 \\
\hline & (1.412) & $(0.253)$ & $(0.695)$ & $(0.613)$ & $(-0.808)$ & (1.598) \\
\hline \multirow{2}{*}{ HORIZON } & 0.024 & 0.010 & 0.009 & 0.053 & 0.025 & 0.026 \\
\hline & (1.294) & $(0.551)$ & $(0.644)$ & $(1.460)$ & $(0.718)$ & $(0.644)$ \\
\hline \multirow{2}{*}{ FOLLOW } & $-0.038^{* *}$ & $-0.018^{*}$ & -0.032 & -0.050 & -0.007 & -0.038 \\
\hline & $(-1.977)$ & $(-1.861)$ & $(-1.453)$ & $(-1.529)$ & $(-0.335)$ & $(-0.982)$ \\
\hline \multirow{2}{*}{ Intercept } & -0.255 & 0.419 & -0.469 & -0.456 & 1.022 & -0.808 \\
\hline & $(-0.490)$ & $(1.403)$ & $(-0.866)$ & $(-0.457)$ & $(1.405)$ & $(-0.793)$ \\
\hline Industry dummies & Yes & Yes & Yes & Yes & Yes & Yes \\
\hline No. of observations & 3,637 & 2,657 & 3,069 & 1,862 & 1,373 & 1,548 \\
\hline Adjusted R-square & 0.052 & 0.046 & 0.061 & 0.094 & 0.066 & 0.233 \\
\hline
\end{tabular}

(T able 4, Panel B continued on next page) 
Panel B: KOSDAQ firms

(Table 4 continued)

\begin{tabular}{|c|c|c|c|}
\hline & \multicolumn{3}{|c|}{ KOSDAQ firms } \\
\hline Dependent Variables: & \multicolumn{3}{|c|}{$A F E$} \\
\hline Sample Period: & 2000-2013 & Excluding 2009-2010 & $2007-2013$ \\
\hline & $(7)$ & (8) & (9) \\
\hline \multirow{2}{*}{ IFRS (indicator) } & -0.005 & 0.004 & -0.003 \\
\hline & $(-0.670)$ & $(0.343)$ & $(-0.537)$ \\
\hline \multirow{2}{*}{$A B S D A$} & $0.128^{*}$ & $0.209^{* * *}$ & $0.131^{* *}$ \\
\hline & $(1.823)$ & $(2.283)$ & $(2.493)$ \\
\hline \multirow{2}{*}{$I F R S \times A B S D A$} & $-0.159^{* *}$ & $-0.226^{* *}$ & $-0.148^{* * * *}$ \\
\hline & $(-2.344)$ & $(-2.555)$ & $(-2.651)$ \\
\hline \multirow{2}{*}{ SIZE } & -0.021 & $-0.011^{* *}$ & -0.023 \\
\hline & $(-1.344)$ & $(-2.128)$ & $(-1.197)$ \\
\hline \multirow{2}{*}{$L E V$} & $0.116^{* * *}$ & $0.091^{* * * *}$ & $0.100^{* *}$ \\
\hline & $(2.776)$ & $(3.546)$ & $(2.087)$ \\
\hline \multirow{2}{*}{ LOSS } & $0.050^{* * * *}$ & $0.031^{* * * *}$ & $0.047^{* * * *}$ \\
\hline & $(4.420)$ & $(3.110)$ & $(3.912)$ \\
\hline \multirow{2}{*}{$R O A$} & 0.099 & 0.031 & 0.048 \\
\hline & $(1.335)$ & $(0.414)$ & $(1.067)$ \\
\hline \multirow{2}{*}{ HORIZON } & -0.001 & -0.004 & 0.001 \\
\hline & $(-0.091)$ & $(-0.595)$ & $(0.156)$ \\
\hline \multirow{2}{*}{ FOLLOW } & $-0.015^{* * *}$ & $-0.016^{* * *}$ & $-0.008 *$ \\
\hline & $(-2.985)$ & $(-3.450)$ & $(-1.696)$ \\
\hline \multirow{2}{*}{ Intercept } & 0.531 & 0.305 & 0.580 \\
\hline & $(1.412)$ & $(2.364)$ & $(1.262)$ \\
\hline Industry dummies & Yes & Yes & Yes \\
\hline No. of observations & 1,775 & 1,284 & 1,521 \\
\hline Adjusted R-square & 0.051 & 0.412 & 0.010 \\
\hline
\end{tabular}

All variables are as defined in Table 1. Robust $\mathrm{t}$-st atistics in parentheses. The symbols ***,**, and * denote significance at the $1 \%, 5 \%$, and $10 \%$ levels, respectively.

Table 5 presents the analyses results for regression equation (10) where we examine the impacts of the mandatory IFRS adoption on information precision. The coefficient estimate of IFRS are significantly positive in full sample and KOSPI subsample (model (1) through (6)). This shows that mandatory IFRS adoption enhances corporate disclosure and improves the precision of analysts' information sets. This finding is consistent with the argument that analysts are encouraged to incorporate more precise information caused by IFRS adoption into their earnings forecasts. However, for KOSDAQ firms, the coefficient of IFRS is negative and statistically not significant across all sample period (model (7) through (9)). These results largely support the view that the imp rovements in analysts' forecast accuracy is brought by improved precision of analysts' information sets after IFRS adoption. 
Table 5. OLS regression of information precision on mandatory IFRS adoption

\begin{tabular}{|c|c|c|c|c|c|c|}
\hline \multicolumn{7}{|c|}{ Panel A: Full sample firms and KOSPI firms } \\
\hline & \multicolumn{3}{|c|}{ (1) Full sample firms } & \multicolumn{3}{|c|}{ (2) KOSPIfirms } \\
\hline Dependent Variables: & \multicolumn{3}{|c|}{ RK } & \multicolumn{3}{|c|}{ RK } \\
\hline \multirow[t]{2}{*}{ Sample Period: } & $2000-2013$ & $\begin{array}{l}\text { Excluding } \\
2009-2010\end{array}$ & $2007-2013$ & $2000-2013$ & $\begin{array}{l}\text { Excluding } \\
2009-2010\end{array}$ & $2007-2013$ \\
\hline & (1) & (2) & (3) & (4) & (5) & (6) \\
\hline \multirow{2}{*}{ IFRS (indicator) } & $0.026^{* * *}$ & $0.031 * * *$ & $0.017 *$ & $0.052^{* * * *}$ & $0.049^{* * n}$ & $0.047^{* * 1}$ \\
\hline & $(2.713)$ & $(2.747)$ & $(1.717)$ & $(3.717)$ & $(3.051)$ & $(3.276)$ \\
\hline \multirow{2}{*}{$A B A C C$} & -0.331 & $-0.322 * * *$ & $-0.352 * * *$ & -0.198 & -0.208 & $-0.202 *$ \\
\hline & $(-5.388)$ & $(-4.293)$ & $(-5.348)$ & $(-1.915)$ & $(-1.618)$ & $(-1.819)$ \\
\hline \multirow{2}{*}{ SIZE } & $-0.090^{* *}$ & $-0.088 * * *$ & $-0.093 * * *$ & -0.097 & $-0.094^{*}$ & -0.102 \\
\hline & $(-21.690)$ & $(-18.328)$ & $(-20.887)$ & $(-16.684)$ & $(-13.677)$ & $(-16.245)$ \\
\hline \multirow{2}{*}{$L E V$} & $0.097^{\prime-1}$ & $0.094 * * *$ & $0.113 * * *$ & 0.123 & $0.097^{-\ldots}$ & 0.168 \\
\hline & $(3.601)$ & $(2.948)$ & (3.914) & $(3.210)$ & $(2.123)$ & $(4.052)$ \\
\hline \multirow{2}{*}{$L O S S$} & $-0.169^{\prime \prime}$ & $-0.177 * * *$ & $-0.163 * * *$ & -0.162 & -0.164 & -0.150 \\
\hline & $(-10.691)$ & $(-9.632)$ & $(-9.582)$ & $(-7.237)$ & $(-6.309)$ & $(-6.107)$ \\
\hline \multirow{2}{*}{$R O A$} & $-0.173^{* *}$ & $-0.187^{* *}$ & $-0.204 * * *$ & $-0.195^{\circ}$ & -0.219 & -0.189 \\
\hline & $(-2.451)$ & $(-2.264)$ & $(-2.651)$ & $(-1.748)$ & $(-1.632)$ & $(-1.560)$ \\
\hline \multirow{2}{*}{ HORIZON } & $-0.145^{* * * *}$ & $-0.149 * * *$ & $-0.137 * * *$ & $-0.134^{* * *}$ & $-0.157^{* * * *}$ & $-0.125^{* * * *}$ \\
\hline & $(-12.878)$ & $(-10.802)$ & $(-11.328)$ & $(-7.539)$ & $(-7.116)$ & $(-6.634)$ \\
\hline \multirow{2}{*}{$F L L W$} & -0.005 & -0.001 & -0.008 & 0.010 & 0.011 & 0.007 \\
\hline & $(-0.876)$ & $(-0.200)$ & $(-1.265)$ & $(1.349)$ & $(1.228)$ & $(0.967)$ \\
\hline \multirow{2}{*}{ Intercept } & $3.576^{\text {*** }}$ & $3.554 * * *$ & $3.638 * * *$ & $3.638^{* * *}$ & $3.685^{* * *}$ & $3.714^{* * *}$ \\
\hline & $(31.673)$ & $(27.268)$ & $(29.942)$ & $(21.487)$ & $(18.229)$ & $(20.620)$ \\
\hline Industry dummies & Yes & Yes & Yes & Yes & Yes & Yes \\
\hline No. of observations & 3,511 & 2,558 & 2,952 & 1,820 & 1,331 & 1,518 \\
\hline Adjusted R-square & 0.375 & 0.362 & 0.392 & 0.357 & 0.335 & 0.380 \\
\hline
\end{tabular}

\begin{tabular}{|c|c|c|c|}
\hline & \multicolumn{3}{|c|}{ (3) KOSDAQ firms } \\
\hline Dependent Variables: & \multicolumn{3}{|c|}{ RK } \\
\hline \multirow[t]{2}{*}{ Sample Period: } & $2000-2013$ & Excluding 2009-2010 & $2007-2013$ \\
\hline & (7) & (8) & (9) \\
\hline \multirow{2}{*}{ IFRS (indicator) } & -0.011 & -0.001 & -0.021 \\
\hline & $(-0.841)$ & $(-0.091)$ & $(-1.545)$ \\
\hline \multirow{2}{*}{$A B A C C$} & $-0.435^{* * * *}$ & $-0.410^{* * * *}$ & $-0.468^{* * *}$ \\
\hline & $(-5.901)$ & $(-4.604)$ & $(-5.937)$ \\
\hline \multirow{2}{*}{$S I Z E$} & $-0.056^{* * *}$ & $-0.059^{* * *}$ & $-0.060^{* * * *}$ \\
\hline & $(-6.500)$ & $(-5.848)$ & $(-6.438)$ \\
\hline \multirow{2}{*}{$L E V$} & 0.054 & 0.059 & 0.053 \\
\hline & $(1.438)$ & $(1.320)$ & $(1.309)$ \\
\hline \multirow{2}{*}{$L O S S$} & $-0.180^{\circ}$ & $-0.193^{* \ldots+}$ & -0.179 \\
\hline & $(-8.340)$ & $(-7.618)$ & $(-7.873)$ \\
\hline \multirow{2}{*}{$R O A$} & -0.150 & $-0.181^{*}$ & $-0.195^{\circ}$ \\
\hline & $(-1.639)$ & $(-1.700)$ & $(-1.943)$ \\
\hline \multirow{2}{*}{ HORIZON } & $-0.155^{\ldots-n}$ & -0.146 & $-0.149^{-\ldots+4}$ \\
\hline & $(-11.017)$ & $(-8.474)$ & $(-9.853)$ \\
\hline \multirow{2}{*}{$F L L W$} & -0.036 & -0.029 & -0.037 \\
\hline & $(-3.869)$ & $(-2.644)$ & $(-3.692)$ \\
\hline \multirow{2}{*}{ Intercept } & $2.951^{* * * *}$ & $2.986^{* * *}$ & $3.038^{* * *}$ \\
\hline & $(13.771)$ & $(12.058)$ & $(13.137)$ \\
\hline Industry dummies & Yes & Yes & Yes \\
\hline No. of observations & 1,691 & 1,227 & 1,434 \\
\hline Adjusted R-square & 0.213 & 0.209 & 0.221 \\
\hline
\end{tabular}

All variables are as defined in T able 1. Robust $\mathrm{t}$-st atistics in parentheses. The symbols ***,**, and * denote significance at the $1 \%, 5 \%$, and $10 \%$ levels, respectively.

Copyright by author(s); $\underline{\mathrm{CC}-\mathrm{BY}}$ 
We investigate the effects of IFRS adoption on the number of analysts following a firm using Equation (11). The results are reported in Table 6 . The all of the estimated coefficients on IFRS are negative and significant at 1 percent level. The number of analysts following a firm significantly decreases after the mandatory adoption of IFRS in all subsamples and sample periods. These results indicate that the change of primary financial statement from unconsolidated ones to consolidated ones caused by IFRS adoption makes financial analysts to spend more time and efforts in providing earnings forecasts and, as consequence, the level of analyst coverage is substantially reduced.

Table 6. OLS regression of analyst coverage on mandatory IFRS Adoption

\begin{tabular}{|c|c|c|c|c|c|c|}
\hline \multicolumn{7}{|c|}{ Panel A: Full Sample firms and KOSPI firms } \\
\hline Dependent Variable: & & $F L L W$ & & & $F L L W$ & \\
\hline \multirow[t]{2}{*}{ Sample Period: } & 2000-2013 & $\begin{array}{l}\text { Excluding } \\
2009-2010\end{array}$ & 2007-2013 & 2000-2013 & $\begin{array}{l}\text { Excluding } \\
2009-2010\end{array}$ & 2007-2013 \\
\hline & (1) & (2) & (3) & (4) & (5) & (6) \\
\hline \multirow{2}{*}{ IFRS (indicator) } & $-0.427^{* * *}$ & $-0.494^{* * * \pi}$ & $-0.397^{* * *}$ & $-0.525^{* * 2}$ & $-0.578^{* * * * 6}$ & $-0.505^{* * * \pi}$ \\
\hline & $(-13.170)$ & $(-13.658)$ & $(-12.164)$ & $(-10.906)$ & $(-11.036)$ & $(-10.394)$ \\
\hline \multirow{2}{*}{$A B A C C$} & -0.317 & -0.344 & $-0.358 *$ & $-0.708 *$ & -0.566 & $-0.979^{* * *}$ \\
\hline & $(-1.531)$ & $(-1.448)$ & $(-1.673)$ & $(-1.864)$ & $(-1.301)$ & $(-2.579)$ \\
\hline \multirow{2}{*}{ SIZE } & $0.468^{* * *}$ & $0.454^{* * *}$ & $0.466^{* * *}$ & $0.531^{* * *}$ & $0.522^{* * *}$ & $0.530^{* * * *}$ \\
\hline & (39.034) & $(36.890)$ & (38.092) & $(30.578)$ & (29.667) & $(29.414)$ \\
\hline \multirow{2}{*}{$L E V$} & $-0.368^{* * *}$ & $-0.461^{* * *}$ & $-0.393^{* * * *}$ & -0.127 & -0.227 & -0.118 \\
\hline & $(-3.570)$ & $(-4.285)$ & $(-3.696)$ & $(-0.736)$ & $(-1.330)$ & $(-0.648)$ \\
\hline \multirow{2}{*}{ LOSS } & 0.057 & 0.056 & $0.084 *$ & -0.021 & -0.022 & 0.027 \\
\hline & (1.194) & $(1.073)$ & $(1.712)$ & $(-0.272)$ & $(-0.266)$ & $(0.325)$ \\
\hline \multirow{2}{*}{$R O A$} & $2.149^{* * *}$ & $1.790^{* * *}$ & $2.122^{* * *}$ & $2.319^{* * *}$ & $2.000^{* * * *}$ & $2.205^{* * *}$ \\
\hline & $(7.840)$ & $(6.287)$ & $(7.505)$ & (4.877) & $(4.080)$ & $(4.484)$ \\
\hline \multirow{2}{*}{ HORIZON } & $0.039 *$ & 0.001 & 0.031 & $0.070^{*}$ & 0.037 & 0.062 \\
\hline & $(1.830)$ & $(0.044)$ & $(1.407)$ & $(1.833)$ & $(0.725)$ & $(1.499)$ \\
\hline \multirow{2}{*}{$D I S P$} & $5.207^{*+1}$ & $5.824^{* *}$ & $5.293^{\ldots+\ldots}$ & $3.990^{* *}$ & $4.157^{* *}$ & $3.858^{* \ldots}$ \\
\hline & $(3.516)$ & $(2.991)$ & $(3.025)$ & (2.999) & $(2.352)$ & $(2.472)$ \\
\hline \multirow{2}{*}{ Intercept } & $-11.876^{* * *}$ & $-11.228^{* \% *}$ & $-11.783^{\text {*** }}$ & $-13.868^{* * *}$ & $-13.406^{* * *}$ & $-13.802^{* * * *}$ \\
\hline & $(-38.477)$ & $(-35.289)$ & $(-37.450)$ & $(-31.478)$ & $(-28.422)$ & $(-30.302)$ \\
\hline Industry dummies & Yes & Yes & Yes & Yes & Yes & Yes \\
\hline No. of observations & 3,601 & 2,601 & 3,141 & 1,894 & 1,385 & 1,613 \\
\hline Adjusted R-square & 0.507 & 0.488 & 0.501 & 0.520 & 0.499 & 0.506 \\
\hline
\end{tabular}

(Table 6, Panel B continued on next page) 
(Table 6 continued)

\begin{tabular}{|c|c|c|c|}
\hline \multicolumn{4}{|l|}{ Panel B: KISDAQ firms } \\
\hline & \multicolumn{3}{|c|}{ (3) KOSDAQ firms } \\
\hline Dependent Variable: & & FLLW & \\
\hline \multirow[t]{2}{*}{ Sample Period: } & $2000-2013$ & Excluding 2009-2010 & $2007-2013$ \\
\hline & (7) & (8) & (9) \\
\hline \multirow{2}{*}{ IFRS (indicator) } & -0.330 & $-0.389^{\cdots \cdots}$ & $-0.286^{*}$ \\
\hline & $(-7.090)$ & $(-6.982)$ & $(-6.293)$ \\
\hline \multirow{2}{*}{$A B A C C$} & -0.184 & -0.449 & -0.063 \\
\hline & $(-0.762)$ & $(-1.507)$ & $(-0.250)$ \\
\hline \multirow{2}{*}{ SIZE } & $0.410^{* * * *}$ & $0.367^{* * *}$ & $0.405^{* * *}$ \\
\hline & $(10.978)$ & $(9.272)$ & $(10.669)$ \\
\hline \multirow{2}{*}{$L E V$} & $-0.571^{* * *}$ & $-0.612^{* * *}$ & $-0.622^{* * *}$ \\
\hline & $(-5.077)$ & $(-4.748)$ & $(-5.494)$ \\
\hline \multirow{2}{*}{ LOSS } & 0.058 & 0.062 & 0.061 \\
\hline & $(1.110)$ & $(1.045)$ & $(1.160)$ \\
\hline \multirow{2}{*}{$R O A$} & 1.896 & $1.543^{\cdots \cdots}$ & $1.889^{\cdots \cdots \cdots}$ \\
\hline & $(5.700)$ & $(4.618)$ & $(5.401)$ \\
\hline \multirow{2}{*}{ HORIZON } & 0.030 & 0.002 & 0.021 \\
\hline & $(1.372)$ & $(0.088)$ & $(0.928)$ \\
\hline \multirow{2}{*}{$D I S P$} & $10.527^{\ldots \ldots}$ & $17.569^{\cdots \cdots}$ & $10.705^{\ldots-m}$ \\
\hline & $(3.140)$ & $(3.469)$ & (3.156) \\
\hline \multirow{2}{*}{ Intercept } & $-10.054^{* * *}$ & $-8.735^{* * * *}$ & $-9.945^{* * *}$ \\
\hline & $(-10.826)$ & $(-9.073)$ & $(-10.536)$ \\
\hline Industry dummies & Yes & Yes & Yes \\
\hline No. of observations & 1,707 & 1,216 & 1,528 \\
\hline Adjusted R-square & 0.336 & 0.327 & 0.338 \\
\hline
\end{tabular}

All variables are as defined in T able 1 . Robust $\mathrm{t}$-st atistics in parentheses. The symbols $* * * * *$, and $*$ denote significance at the $1 \%, 5 \%$, and $10 \%$ levels, respectively.

\section{ROBUSTNESS TESTS}

\subsection{An Alternative Measure for Earnings Management: Total Accrual}

In testing Hypothesis 2, we use absolute discretionary accruals ( $A B S D A)$ for the earnings management measure. We check the robustness of our results by employing an alternative measure. Specifically, we replace absolute discretionary accruals $(A B S D A)$ with absolute accruals $(A B A C C)$ in Equation (9) and estimate the regression equation. Absolute Accruals $(A B A C C)$ is the absolute difference between net income and cash flow, deflated by total asset. In this unreported test, the results are similar to those reported in Table 4.

\subsection{Analyses of Analysts' Public and Private Information}

Our main interest is the impacts of mandatory IFRS adoption on the precision of total information (public and private). In this subsection, we examine whether the improvements in the precision of total information is attributable to the improvements in public information or private information.

Conventional wisdom states that enhanced disclosures and transparency after IFRS adoption would improve analysts' public information. However, the theoretical relation between mandatory IFRS adoption and the precision of private information is ambiguous. Kim and Verrecchia (1991) document that increased level of firm disclosures discourages analysts' incentives to produce private information. If this is the case, mandatory IFRS adoption is unlikely to improve the precision of private information. In contrast, Kim and Verrecchia (1994, 1997) report that increased disclosure level could complement analysts' private knowledge, allowing analysts to develop more private information. Lundholm (1991) finds that increased public information facilitates the allocation of private information. In this case, mandatory IFRS adoption might lead to more precise private information. 
Byard and Shaw (2003) and Byard et al. (2011) show that enhanced disclosure increases the precision of both public and private information sets, implying that analysts' public information complements their private information. In order to empirically investigate this issue, we use Barron et al. (1998) measures as defined in equations (4), (5) and (6) to capture the precision of analysts' public and private information.

In examining the effects of mandatory IFRS adoption on analysts' public information, private information, and analysts' consensus, we employ the decile ranks of PUBLIC, PRIVATE and CONSENSUS to reduce the skewness problem. We also include all the control variables used in equation (10).

In untabulated results, the coefficient of IFRS is positive and statistically significant in the regression with PRIVATE as dependent variable, which implies that mandatory IFRS adoption encourages analysts to incorporate private information into their earnings forecasts. However, the coefficient is not statistically significant in the regression where PUBLIC is the dependent variable. This evidence suggests that IFRS adoption is not likely to improve the quality of public information.

As a result, it appears that improvements in the precision of total information, as reported in Table 5, is attributable to the improved precision of private information not public information. The enhancements in analysts' private information is consistent with previous findings that increased level of firm disclosures improves analysts' private information (Frankel, Kothari, \& Weber, 2006; Barron et al., 1998). Also, the coefficient on IFRS is negatively significant in the regression with CONSENSUS as dependent variable. This indicates that IFRS adoption is more likely to increase the precision of analysts' private information than that of analysts' public information.

In short, the results show that mandatory IFRS adoption improves the analysts' information environment through the increased precision of private information rather than public information. This finding suggests that the positive association between the precision of total information and IFRS adoption is caused by the complementary relation between public and private information.

\section{CONCLUS ION}

This study investigates the effects of the 2011 mandatory adoption of IFRS by Korean firms on financial analysts' information environment. First, we find that mandatory IFRS adoption is followed by statistically significant decreases in analysts' forecast errors and forecast dispersion, supporting the claim that mandatory IFRS adoption improves analysts' information environment. Second, we further test if the increases in analysts' forecast accuracy is the consequence of more opportunities to manage earnings towards analysts' forecasts after IFRS adoption. We find empirical evidence consistent with this conjecture, but in KOSDAQ firms only. Third, we find that mandatory IFRS adoption improves the precision of analysts' information sets in full sample firms and KOSPI firms. However, this does not hold for KOSDAQ firms. Finally, we find that the mandatory IFRS adoption reduces the degree of analyst coverage. In summary, mandatory IFRS adoption in Korea improves the information sets, especially for private information, promotes analysts to incorporate the improved information into their earnings forecasts, and increases the accuracy of forecasts especially for KOSPI firms.

\section{ACKNOWLEDGMENTS}

Kyoung-Min Kwon's work was supported by 2014 Hongik University Research Fund.

\section{AUTHOR BIOGRAPHIES}

Saerona Kim received her BBA in 2005 and MS in Accounting in 2009 from Dongguk University. She also received her PhD in Accounting in 2013 from Dongguk University. She had taught various courses such as financial Accounting, managerial accounting, and tax accounting at Dongguk University and Chung-Ang University and currently she works as an Assistant Professor of Tax \& Accounting at Soongeui Women's college. E-mail: ksaerona@hanmail.net 
Noolee Kim received his BBA in 1995 and MS in Finance in 1997 from Korea University. He had worked for the Bank of Korea and received his $\mathrm{PhD}$ in Finance in 2009 from Michigan State University. He had taught various courses such as financial management, corporate finance, and security markets at Korea University and Michigan State University. Currently he works as an Assistant Professor of Finance at Hanyang University-ERICA. E-mail: nooleekim@hanyang.ac.kr

Kyoung-Min Kwon received his BBA in 2000 from Korea University and MS in Finance in 2005 from University of Illinois at Urbana-Champaign. He had worked for SK Corporation and received his PhD in Finance in 2012 from Michigan State University. He had taught various cours es such as financial management, corporate finance, and investments at Michigan State University. He is currently an Assistant Professor of Finance at Hongik University. Email: km.kwon@hongik.ac.kr (Corresponding author)

\section{REFERENCES}

Abarbanell, J., \& Lehavy, R. (2003). Biased forecasts or biased earnings? The role of reported earnings in explaining apparent bias and over/underreaction in analysts' earnings forecasts. Journal of Accounting and Economics, 36(1-3), 105-146.

Ahmed, A. S., Neel, M., \& Wang, D. (2013). Does mandatory adoption of IFRS improve accounting quality? Preliminary evidence. Contemporary Accounting Research, 30(4), 1344-1372.

Ashbaugh, H., \& Pincus, M. (2001). Domestic accounting standards, international accounting standards, and the predictability of earnings. Journal of Accounting Research, 39(3), 417-434.

Bae, K-H., Tan, H., \& Welker, M. (2008). International GAAP differences: The impact on foreign analy sts. The Accounting Review, 83(3), 593-628.

Ball, R. (2006). International Financial Reporting Standards (IFRS), pros and cons for investors. Accounting and Business Research, 36(Sup 1), 5-27.

Ball, R., Kothari, S. P., \& Robin, A. (2000). The effect of international institutional factors on properties of accounting earnings. Journal of Accounting and Economics, 29(1), 1-51.

Ball, R., Robin, A., \& Wu, J. S. (2003). Incentives versus standards: Properties of accounting income in four East Asian countries. Journal of Accounting and Economics, 36(1-3), 235-270.

Bannister, J. W., \& Newman, H. A. (1996). Accrual usage to manage earnings toward financial analysts' forecasts. Review of Quantitative Finance and Accounting, 7(3), 259-278.

Barron, O. E., Kim, O., Lim, S. C., \& Stevens, D. E. (1998). Using analy sts' forecasts to measure properties of analy sts' information environment. The Accounting Review, 73(4), 421-433.

Barth, M. E., Landsman, W. R., \& Lang, M. H. (2008). International accounting standards and accounting quality. Journal of Accounting Research, 46(3), 467-498.

Bhushan, R. (1989). Firm characteristics and analy st following. Journal of Accounting and Economics, 11(2-3), $255-274$.

Botosan, C. A., Plumlee, M. A., \& Xie, Y. (2004). The role of information precision in determining the cost of equity capital. Review of Accounting Studies, 9(2), 233-259.

Byard, D., Li, Y., \& Yu, Y. (2011). The effect of mandatory IFRS adoption on financial analysts' information environment. Journal of Accounting Research, 49(1), 69-96.

By ard, D., \& Shaw, K. W. (2003). Corporate disclosure quality and properties of analy sts' information environment. Journal of Accounting, Auditing and Finance, 18(3), 355-378.

Chen, H., Tang, Q., Jiang, Y., \& Lin, Z. (2010). The role of international financial reporting standards in account ing quality Evidence from the European Union. Journal of International Financial Management \& Accounting, 21(3), $220-278$.

Choi, F. D. S., \& Meek, G. K. (2004). International accounting (5th ed.). Upper Saddle River, NJ: Prentice Hall.

Chung, R., Kim, J-B., \& Kim, O. (2004). Corporate governance and analysts' public vs. private information: A cross-country study (Working paper). College Park, MD: University of Mary land.

Clement, M. B. (1999). Analy sts forecast accuracy: Do ability, resources, and portfolio complexity matter? Journal of Accounting and Economics, 27(3), 285-303.

Cotter, J., Tarca, A., \& Wee, M. (2012). IFRS adoption and Analysts' earnings forecasts: Australian evidence. Accounting and Finance, 52(2), 395-419.

Daske, H., Hail, L., Leuz, C., \& Verdi, R. (2008). Mandatory IFRS reporting around the world: Early evidence on the economic consequences. Journal of Accounting Research, 46(5), 1085-1142.

Dechow, P. M., Sloan, R. G., \& Sweeney, A. P. (1995). Detecting earnings management. The Accounting Review, $70(2), 193-$ 225.

DeFond, M. L., \& Hung, M. (2003). An empirical analysis of analysts' cash flow forecasts. Journal of Accounting and Economics, 35(1), 73-100.

Degeorge, F., Patel, J., \& Zeckhauser, R. (1999). Earnings management to exceed thresholds. The Journal of Business, 72(1), 1- 
33.

Duru, A., \& Reeb, D. M. (2002). International diversification and analysts' forecast accuracy and bias. The Accounting Review, $77(2), 415-433$

Frankel, R., Kothari, S. P., \& Weber, J. (2006). Determinants of the informativeness of analy st research. Journal of Accounting and Economics, 41(1-2), 29-54.

Glaum, M., Baetge, J., Grothe, A., \& Oberdörster, T. (2013). Introduction of International Accounting Standards, disclosure quality and accuracy of analysts' earnings forecasts. European Accounting Review, 22(1), 79-116.

Healy, P. M., Hutton, A. P., \& Palepu, K. G. (1999). Stock performance and intermediation changes surrounding sustained increases in disclosure. Contemporary Accounting Research, 16(3), 485-520.

Hodgdon, C., Tondkar, R. H., Harless, D. W., \& Adhikari, A. (2008). Compliance with IFRS disclosure requirements and individual analysts' forecast errors. Journal of International Accounting, Auditing and Taxation, 17(1), 1-13.

Hope, O-K. (2003a). Analyst following and the influence of disclosure components, IPOs and ownership concentration. AsiaPacific Journal of Accounting \& Economics, 10(2), 117-141.

Hope, O-K. (2003b). Disclosure practices, enforcement of accounting standards, and analysts' forecast accuracy: An international study. Journal of Accounting Research, 41(2), 235-272.

Hutton, A. P. (2005). Determinants of managerial earnings guidance prior to regulation fair disclosure and bias in analysts' earnings forecasts. Contemporary Accounting Research, 22(4), 867-914.

Jarrett, J. (2007). Deloitte CEO applauds SEC decision on IFRS recognition. Deloitte Touche Tohmatsu. Retrieved June 10, 2012, from http://www.iasplus.com/en/binary/resource/0706quigley.pdf

Jeanjean, T., \& Stolowy, H. (2008). Do accounting standards matter? An exploratory analy sis of earnings management before and after IFRS adoption. Journal of Accounting and Public Policy, 27(6), 480-494.

Kim, J-B., \& Shi, H. (2012). Voluntary IFRS adoption, analy st coverage, and information quality: International evidence. Journal of International Accounting Research, 11(1), 45-76.

Kim, J-B., \& Yi, C. H. (2011). Foreign equity ownership and disclosure transparency in emerging markets: Evidence from Korea (Working paper). Kowloon: City University of Hong Kong.

Kim, O., \& Verrecchia, R. E. (1991). Trading volume and price reactions to public announcements. Journal of Accounting Research, 29(2), 302-321.

Kim, O., \& Verrecchia, R. E. (1994). Market liquidity and volume around earnings announcements. Journal of Accounting and Economics, 17(1-2), 41-67.

Kim, O., \& Verrecchia, R. E. (1997). Pre-announcement and event-period private information. Journal of Accounting and Economics, 24(3), 395-419.

Lang, M. H., Lins, K. V., \& Miller, D. P. (2003). ADRs, analysts, and accuracy: Does cross listing in the United States improve a firm's information environment and increase market value? Journal of Accounting Research, 41(2), 317-345.

Lang, M. H., \& Lundholm, R. J. (1996). Corporate disclosure policy and analy st behavior. The Accounting Review, 71(4), 467492.

Leuz, C. (2003). IAS versus U.S. GAAP: Information asymmetry-based evidence from Germany's new market. Journal of Accounting Research, 41(3), 445-472.

Lundholm, R. J. (1991). Public signals and the equilibrium allocation of private information. Journal of Accounting Research, 29(2), 322-349.

Matsumoto, D. A. (2002). Management's incentives to avoid negative earnings surprises. The Accounting Review, 77(3), 483514.

McInnis, J., \& Collins, D. W. (2011). The effect of cash flow forecasts on accrual quality and benchmark beating. Journal of Accounting and Economics, 51(3), 219-239.

Paananen, M. (2008). Fair value accounting for goodwill under IFRS: An exploratory study of the comparability in France, Germany, and the United Kingdom (Working paper). Retrieved July 26, 2011, from http://ssrn.com/abstract=1275803

Paananen, M., \& Lin, H. (2009). The development of accounting quality of IAS and IFRS over time: The case of Germany. Journal of International Accounting Research, 8(1), 31-55.

Tan, H., Wang, S., \& Welker, M.(2011). Analy st following and forecast accuracy after mandated IFRS adoptions. Journal of Accounting Research, 49(5), 1307-1357 